\title{
PECULIARITIES OF THE RELATIONSHIP BETWEEN EDUCATION AND THE LABOR MARKET IN THE REPUBLIC OF ARMENIA
}

\begin{abstract}
The article discusses the interrelated relationship between education and the labour market. The balance of the labour market-university system is considered as the main problem. It is substantiated that today, with the state system's management, it is possible to achieve greater efficiency. In the absence of public administration, employers and universities find it difficult to find systematized solutions independently. The article presents some of the most relevant solutions, which are more practical for urgent correction of the situation.
\end{abstract}

Keywords: education, economic development, human capital, professional qualification.

\section{Introduction}

Theoretically, some mechanisms showcase how education affects economic growth.

- According to neoclassical growth models, education increases the total volume of people engaged in the workforce, which in its own right increases the productivity levels overall. With that, a higher balanced level of productivity is achieved.

- According to endogenous growth theory, education has an impact on innovative capital and innovative technology growth. Inevitably, doing things more efficiently will bring rapid economic development.

Before the early 2000s, many academic studies and papers dedicated to displaying the positive relationship between a good education and economic development were mainly concentrated on the length of education measured in years. Unfortunately, considering only quantitative variables as quality descriptions and leaving qualitative ones out, the result was simply wrong. That logic would imply that the experience of being a student at the best college for one year is the same as being a student at a mediocre college for one year: which is not valid. According to Eric A. Hanushek, Dennis D. Kimko (2000). Schooling, Labor-Force Quality, and the Growth of Nations, the effect of the number of years studied on the initial model quickly drop into nothing after they plug in 
qualitative variables into it. Further studies also strengthen that result, as they take the primary descriptive variable, the qualitative one.

\section{Literature review}

Quite a lot of research has been devoted to human capital as a problem of ensuring economic growth. Many scientists, considering the connection between human capital and labour productivity, prioritize the role of education. Ángel de la Fuente (2003) noted that each additional year of study could lead to $3.1 \%$ economic growth in the long run. According to Eric A. Hanushek, Dennis D. Kimko (2000), the effect of the number of years studied on the initial model quickly dropped into nothing after they plug in qualitative variables into it . Antip'ev A.G. (2012) proves that in order to create an innovative economy it is necessary to develop an innovative class, which also confirms the need for quality assurance. Luk'janova K.K. (2016) From the analysis of the work, it can be assumed that the state management mainly conditions the positive effect of the solution of the employment problem. According to Astahanova R.A. (2018): It is preferable to invest in education among young people, taking into account the ability to accumulate knowledge. That is, all these changes need to be made starting from the school curriculum.

It turns out that in addition to the number of years, it is necessary to provide a correspondingly high level of education, the successful implementation of which requires the intervention of the state. As knowledge tends to accumulate, it is necessary to direct investments from school upon completing university education. In this article, we will discuss the situation of higher education.

Thus, in the Republic of Armenia, having a situation inconsistent with the abovementioned coordinating conclusion and varying professional skills, a question arises: How to balance the labour market-university system? How to ensure economic growth through it?

\section{Research methods}

During our research, the methodology of sociological survey and cross-comparison of results was used.

\section{Main article}

From the claims mentioned above, we can make conclusions on Armenia's educational system. Converting the 10-year school curriculum into 12 years is not effective and sometimes even harmful if no qualitative changes were taken place. A need 
arises to compare the difference between the knowledge gained from additional two years and the impact of that knowledge on the economy and the economy's loss after spending extra two years at school, not working. On the other hand, there is an opinion regarding changing the 4-year bachelor's degree program into 2.5 to 6 years, giving the students a choice. A student will gain the same amount of knowledge in a shorter period (of course, assuming a rational student that will choose the perfect period to gain the knowledge as they would in the 4-year period.). On the other hand, there will be students who will opt for the six-year option. This will create an imbalance, which will lead to an even more unbalanced relationship between the labour market and the proposed future employees by profession, which will affect the economic growth rate.

Viewing education as means of capital, we need to mention several aspects.

- Investment in education most definitely has a positive impact in the long run.

- Knowledge has both cumulative and obsolete effects and more.

Employees who realize the need to improve their professional qualifications are ready to invest in it, but not all of them have the time and financial resources. On the other hand, the employers are not so keen on making those investments themselves and instead find a compatible candidate from the labour market, as it is cheaper (given that there is a candidate in the market). The problem lies in the imbalance in the labour market on future candidates, the solution of which will be addressed below.

The cumulative nature of education and skills allows us to create an optimal scheme for investing in this capital type during an individual's life. From an investment perspective, we need to pay close attention to a younger generation, as a good education is a cornerstone for having a competitive professional skillset in the future. Astahanova(2018).

In addition to problems in the educational system, there is a need to provide the employees with appropriate jobs, and first of all, pay attention to ones that require a high skill level. Unfortunately, in the Republic of Armenia, a considerable amount of workforce occupies workplace not according to their qualification, but also in a place that does not correspond with their knowledge and skill. In addition to improving the problems in the field of education, there is also a need for relevant jobs to apply the acquired knowledge according to the goal as effectively as possible. According to the Statistical Yearbook of Armenia, labour resources according to education statistics showcases that in 2018 and 2019, there are 487.3 and 551.5 thousand individuals with higher and postgraduate education in Armenia, respectively. Several questions arise: will there be jobs available in line with the increase in numbers? How many of those jobs will correspond to the 
professions of employees? Will the proposed salaries meet the expectations of incoming employees and employees getting a raise?

Why is there an imbalance? In order to answer those questions, we need to take a close look at the following scheme:

University/college admissions followed by educational process and eventually getting hired.

Most school graduates who excelled in their studies, not having a particular profession in mind, go for prestigious universities' most prestigious faculties. Simultaneously, students who did not have excellent academic achievements in school choose less prestigious universities, and students with lesser academic knowledge go with the principle of arbitrary university-arbitrary profession. This logic is the same for most school graduates.

After getting into university, some students drop out due to the educational program's incompatibility or low academic standing. Furthermore, during the employment stage, there are students with specific high professional skills and many low-level students who actually do not meet the respective professional standards.

From the above, it can be concluded that some of this uncertainty and incompatibility with the profession may fade away since this process is a controllable one.

In today's reality, the result mentioned above is very applicable to issues in Armenia. There is a big difference between the labour market needs in terms of quality, the relevance of the relevant profession, and the number of students studying in the relevant domain. There is a need to reform the curriculum to adapt it to the emerging industries in the leading international markets, in accordance with the specialists required within the country. It is evident that it is better to have a fixed, albeit a small number of high-level economists graduates each year in addition to improving the curriculum, who will be immediately transferred to the relevant jobs, than to have several times higher-level middle-level economists, some of whom may work in the future, while others, in the hope of finding a job, change their profession, causing oversaturation in other fields. Involuntarily force future graduates of other fields (mostly not so competitive ones) to change their professional orientation due to the scarcity or lack of jobs in the relevant job market, essentially make the knowledge gained pointless (because very little or not at all) and thus lower investment in education (for that person). For instance, an inefficiency occurs when someone who has studied finances and then narrowed professional skillset to risk management is hired as a sales specialist, which will inevitably create inefficiency 
in economic growth in terms of education and lead to a drop in economic growth. This situation will be observable in an optimized system.

The inquiries prove the incompatibility of the labour market requirements and the specialists trained in the educational system. Employers and employees in the fields of education, finance, IT, management and art took part in the survey.

Let's present the most remarkable results.

Question 1 . Are you satisfied with the quality of education of your future employees?

The results of the survey are as follows:

\begin{tabular}{|l|c|c|c|}
\hline \multirow{2}{*}{ Sphere } & Survey employers & \multicolumn{2}{c|}{ Answers } \\
\cline { 2 - 4 } & & Satisfied & Not \\
& & & satisfied \\
\hline Education & 30 & $25.8 \%$ & $74.2 \%$ \\
\hline Finance & 37 & $34.6 \%$ & $65.4 \%$ \\
\hline IT & 32 & $45.6 \%$ & $54.4 \%$ \\
\hline Management & 30 & $43.7 \%$ & $56.3 \%$ \\
\hline Art & 30 & $67.3 \%$ & $32.7 \%$ \\
\hline
\end{tabular}

According to the survey results, it is clear that the employers are not satisfied with the quality of the education of the university graduates in any of the areas identified by our research. This proves that the connection between the labour market and education is not very effective.

The next question was, what exactly is not enough for employers?

The results of the survey were distributed in the following proportions (Table 1).

\begin{tabular}{|c|c|}
\hline Sphere & \multicolumn{1}{c|}{ Employers' Responses } \\
\hline Education & $\begin{array}{l}\text { The key employers in this field are mostly not satisfied with the } \\
\text { level of knowledge of foreign languages, professional knowledge and } \\
\text { skills }\end{array}$ \\
\hline Finance & \multicolumn{1}{|c|}{$\begin{array}{l}\text { Employers in this area stressed the main gap in the graduates' } \\
\text { lack of mathematical knowledge, basic international and local financial }\end{array}$} \\
\hline
\end{tabular}




\begin{tabular}{|c|c|}
\hline & $\begin{array}{l}\text { models, knowledge of their functions, skills, graduates lack creativity, } \\
\text { low adaptability, and difficulties in foreign language operations in the } \\
\text { professional field. }\end{array}$ \\
\hline IT & $\begin{array}{l}\text { IT is probably the most discussed field. Here the employers } \\
\text { mainly complain that the university education is more theoretical, the } \\
\text { graduates do not have practical skills. Simultaneously, the following is } \\
\text { more problematic in this area. The world is becoming more universal. } \\
\text { Graduates must have enough flexibility to acquire new technical } \\
\text { knowledge and acquire new skills quickly. Add to this the insufficient } \\
\text { knowledge of foreign languages }\end{array}$ \\
\hline Management & $\begin{array}{l}\text { Employers see problems in management. Graduates of this } \\
\text { profession are also armed with theoretical knowledge, lack practical } \\
\text { skills and abilities. Problems arise, especially when graduates in the } \\
\text { management process encounter cooperation with foreign } \\
\text { organizations. Graduates lack the flexibility of thought, adaptability, the } \\
\text { ability to cooperate with foreign nations, states, which cause problems } \\
\text { in building management. Knowledge of several foreign languages is } \\
\text { also very important here, which is also not considered sufficient by the } \\
\text { surveyed employers. }\end{array}$ \\
\hline Art & $\begin{array}{l}\text { It is probably the only art in the observed spheres in which the } \\
\text { employers were more or less satisfied, but there are also many } \\
\text { problems here. Employers' grievances were mainly since artists kept } \\
\text { their distance from the modern technological world, which sometimes } \\
\text { causes problems, especially when it is necessary to use a } \\
\text { technological solution or software. }\end{array}$ \\
\hline
\end{tabular}

Table 1. Employers' answers

The presented results are only a part of the existing problems. The next most problematic issue in the labour market-education chain is wages. It is also necessary to consider whether highly qualified specialists, being employed in their profession, are satisfied with the offered salary. We also surveyed to find out this problem. Present the results (Table 2.) . 


\begin{tabular}{|c|c|c|c|}
\hline \multirow{2}{*}{ Sphere } & \multirow{2}{*}{ Number of specialists } & \multicolumn{2}{|c|}{ Responses } \\
\cline { 3 - 4 } & & Satisfied & Not satisfied \\
\hline Education & 40 & $27.4 \%$ & $72.6 \%$ \\
\hline Finance & 35 & $36.6 \%$ & $63.4 \%$ \\
\hline IT & 40 & $46.9 \%$ & $53.1 \%$ \\
\hline Management & 32 & $41.8 \%$ & $58.2 \%$ \\
\hline Art & 36 & $26.2 \%$ & $73.8 \%$ \\
\hline
\end{tabular}

Commenting on the survey results, we should mention that the most satisfied with the salary are the employees in the field of IT, and the most dissatisfaction comes from the employees in the field of education. As stated by the Republic of Armenia State Statistical Service, this is realistic since the expenditures on education and science in relation to GDP have a steadily decreasing rate (fig. 1) (Statistical Committee of the Republic of Armenia).

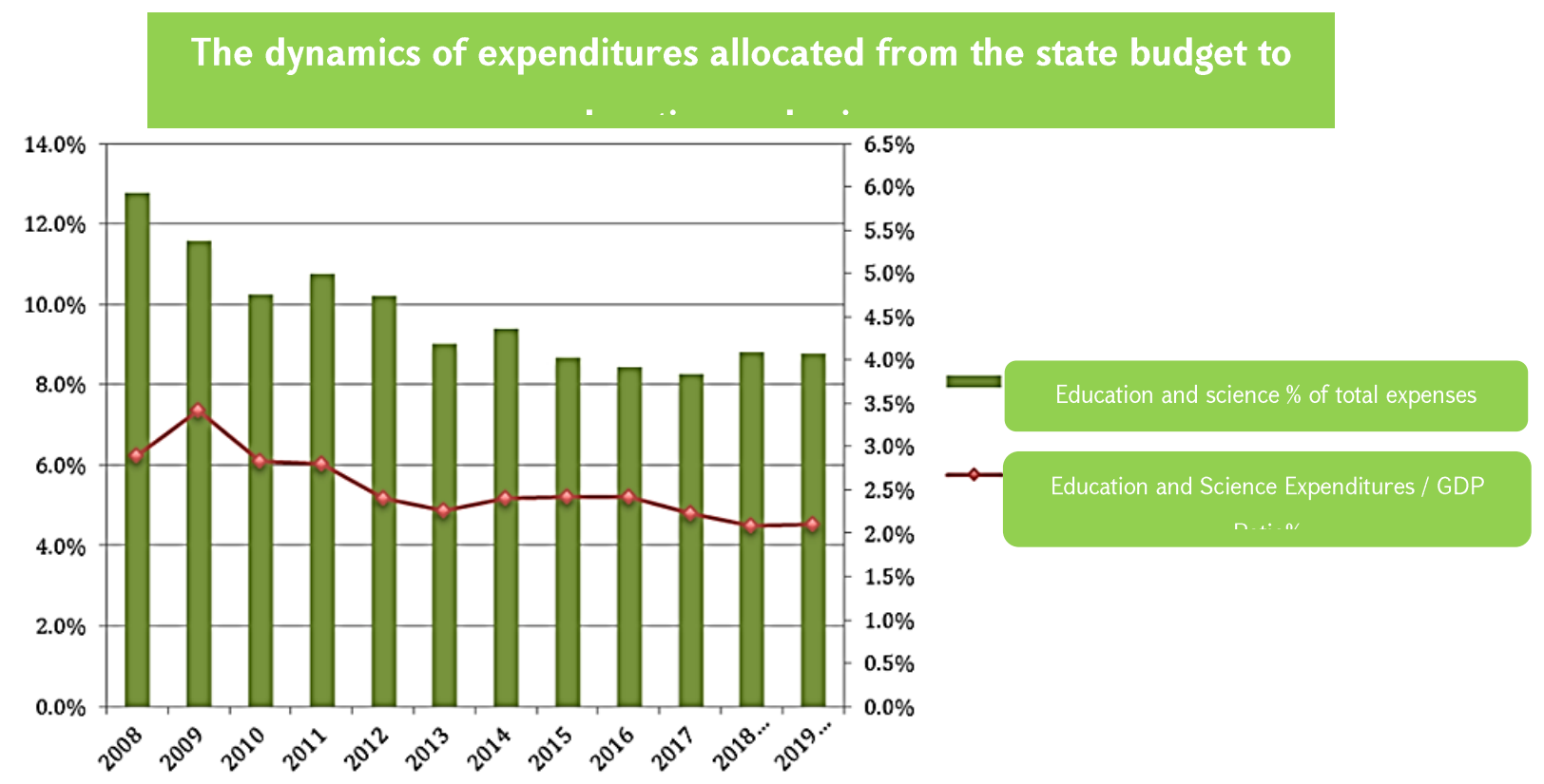

Figure 1 .

\section{Results}

So, how to solve the problem of the student's choice of profession, then the uncertainty of finding a job in the labour market, how to provide employers with qualified specialists? The management of uncertainty may be as follows: For example, to make it transparent and accessible for students, the approximate possible salary levels to be 
expected after completing each university degree, having the statistics of previous years. Establish the exact number of available places calculated for each university faculty, which will meet the labour market requirements.

To provide employers with appropriate professional qualifications, it is necessary to involve employers in the education system. That way, they will be able to train their future employees. And how to involve them in the education system? Consider a few ways to solve the problem.

- As a result of the state management of the problem, greater efficiency can be achieved. The state can offer employers to conduct their own standardized training in relevant educational institutions and receive a decent rent in return. In this case, all parties will benefit. The state will ensure economic growth in the long run, employers will have a group of specialists who meet their requirements, and students will have their respective jobs and expected salaries.

- The next option is that the employers create their own educational institutions next to their enterprises, where they organize both training and internship, later hiring them. And in that case, the question arises: why have educational institutions? Why waste so much state money when every employer has to create an educational centre following its requirements?. On the other hand, the education received in these centres may not be comparable with the educational systems of other countries, the qualifications will be unrecognizable for other countries.

- Next, it is the educational institutions that can invite employers for joint teaching of different subjects. The educational institution will also benefit here, having a highly qualified, practical teacher and an employer who will have the opportunity to choose his future employee.

- The next and perhaps most difficult but key task is to get the employer involved in the curriculum development process. The employer can present his / her requirements regarding the educational level of the future graduate. In this case, the employer can organize the internship, thus developing the students' practical skills.

\section{Conclusion}

Many studies indicate the link between investment in education and economic growth. Systemic measures are needed to improve the economy. By considering a person as the main capital of the modern economy, there is a need to create the necessary conditions to accumulate and renew knowledge. It is essential to provide those with highly professional skills with appropriate work in the internal labour market. 
Furthermore, in educational institutions, it is necessary to train specialists in accordance with the labour market requirements. The state-run process can be more efficient; however, employers can find relatively effective solutions to the situation on their own by providing their own staff.

\section{References}

Antip'ev A.G. (2012) Problemy vzaimodejstvija vuzov i rabotodatelej na rynke truda // Alma mater = Vestn. vyssh. shkoly. - N 4. - S.16-20.

Astahanova R.A. (2018) Investicii $v$ obrazovanie: teoriya $i$ metodologiya. Fundamental'nye issledovaniya.

de la Fuente, Ángel. (2003) Human Capital in a Global and Knowledge-Based Economy.

Part 2. Assessment at the EU Country Level. Recercat Principal.

Eric A. Hanushek, Dennis D. Kimko(2000) Schooling, Labor-Force Quality, and the Growth of Nations.

Eroshin V.I. (2014) Obrazovanie kak mnogootraslevaya sfera vosproizvodstva chelovecheskogo kapitala [Education as DiversifiedScope Reproduction of Human Capital]. Nauka i shkola. (4). 13-24.

Kruss, G., McGrath, S., Petersen, I. H., \& Gastrow, M. (2015). Higher education and economic development: The importance of building technological capabilities. International Journal of Educational Development, 43, 2231. https://doi.org/10.1016/j.ijedudev.2015.04.011

Lee, Doo Won, Tong Hun Lee (1995). Human Capital and Economic Growth. Tests Based on the International Evaluation of Educational Achievement. Economics Letters 47: 219-225.

Luk'janova K.K. (2016) Zarubezhnyj opyt regulirovanija zanjatosti naselenija, Vestnik Juzhno-Ural'skogo gosudarstvennogo universiteta. Serija: Jekonomika i menedzhment, 2016, vol. 10, issue 3, 109-115.

Shchetinin V. P. (2003). The Human and Material Capital: Difference and Similarity // MEiMO. No 8.

Wang Y., Liu S. (2016) Education, Human Capital and Economic Growth: Empirical Research on 55 Countries and Regions (1960-2009) // Theoretical Economics. № 6. - p. 347-355.

https://www.armstat.am/am/ (available 16/03/2021) 